\title{
Significance of Protein: Creatinine value in PIH
}

\author{
Hanumant V Nipanal ${ }^{*}$, S Sushmitha ${ }^{2}$ \\ ${ }^{1,2}$ Assistant Professor, Dept. of Obstetrics and Gynaecology, ${ }^{1,2}$ Gadag Institute of Medical Sciences Malasamudra Karnataka, India
}

*Corresponding Author: Hanumant V Nipanal

Email: hanumant.1210@rediffmail.com

Received: $22^{\text {ed }}$ February 2019

Accepted: $23^{\text {rd }}$ April, 2019

\begin{abstract}
Objectives: To evaluate the significance of the urine protein to creatinine value in hypertensive pregnant patients.

Design: This is a single group comparison study of a single group of 240 subjects.

Setting: This study was conducted in the Department of OBG, JIPMER, Pondicherry, a tertiary care hospital south India, from April 2010 to march 2013.

Materials and Methods: Morning urine sample was sent for urine protein and creatinine value. Rest of the 24 hour urine collected and tested for 24-hour urine protein value.

Main Outcome Measures: The spot urine protein to creatinine value significantly correlates with 24-hour urine protein value. ( $\mathrm{r}=0.98$; $\mathrm{P}<0.0001$ ). The protein to creatinine value for significant proteinuria was 0.285 . The sensitivity was $100 \%$. Specificity was 99 . The positive predictive value $100 \%$. Negative predictive values was $99 \%$.

Results: The urine protein to creatinine value for significant proteinuria was 0.285 .

Conclusion: The urine protein to creatinine value can be used as an alternative to 24 hour urine protein for clinical purposes.
\end{abstract}

Keywords: Protein to creatinine value, Hypertension in pregnancy.

\section{Introduction}

Hypertension in pregnancy complicate up to $10 \%$ of pregnant women. It is a major cause of maternal morbidity and mortality. ${ }^{1}$

Hypertension in pregnancy is a multisystem disorder of an unknown aetiology, with more than or equal to $140 \mathrm{~mm}$ of $\mathrm{Hg}$ systolic and $90 \mathrm{~mm}$ of $\mathrm{Hg}$ diastolic Blood pressure, with proteinuria after 20 weeks of pregnancy in previously normotensive and non-proteinuric patients. ${ }^{1}$ If $300 \mathrm{mg}$ or more of protein in a 24 -hour urine specimen is considered as proteinuria in pregnancy. ${ }^{2}$

One complete day urine collection method is cumbersome. It has so many for protein errors. Most obvious error is variable and complete collection is difficult. It may be inconvenient for many patients. There are incidences of delay in availability of results. Patient may deliver before the arrival of results. Difficulty in arranging storage and staff inadequacy are added problems. Admission of patient for the test itself is burden to hospital.

Urine protein to creatinine value may be a good solution for the above mentioned problems. Since it has shown good results and showed comparable reports with the 24-hour urine protein.3-5 So urine protein to creatinine value can be used as an alternative to 24 hour urine protein for clinical purposes.

\section{Aims and Objectives}

To evaluate the significance of the urine protein to creatinine value in hypertensive pregnant patients.

\section{Materials and Methods}

This study was conducted in the Department of OBG, JIPMER, Pondicherry, a tertiary care hospital south India, from April 2010 to March 2013.
It consists of 240 patients of single group. This is a comparative study. Calculation of samle size was done by using the standard formula for estimating the sensitivity of a new test. It was estimated with a sensitivity of urine protein to creatinine value for significant proteinuria as $95 \%$, with a $5 \%$ of level of significance and $4 \%$ precision.

\section{Inclusion Criteria}

Pregnant women who have completed 20 weeks of gestation with hypertension of $140 / 90 \mathrm{mmHg}$ or higher on two occasions, at least 6 hours apart, were included in the study.

\section{Exclusion Criteria}

Patient's renal problems and diabetics were excluded. Even patients suffering from urinary tract infections also taken out from the study.

Every patients details like demographic profile, gestational age, blood pressure, urine protein to creatinine value and 24-hour urine protein values were studied. The patient had been informed with proper explanation in native language. They were enrolled after their consent for the test.

Morning urine sample was sent for urine protein and creatinine value. Rest of the 24 hour urine collected and tested for 24-hour urine protein value.

Urine protein value obtained by the colorimetric method. The modified Jaffe's method was used for urine creatinine value estimation with a standard auto analyser. The sensitivity, specificity, and positive and negative predictive values were calculated for different protein to creatinine value.. Receiver operating characteristic (ROC) curves were used for comparisons.

\section{Results}

Total recruited patients were 240 . Twenty seven delivered 
before completion of urine collection. Twenty three patients urine collection was incomplete. Seven patients discontinued. Urinary tract infection was found in 7 patients. Therefore 64 patients excluded from the study at initial step only. Remaining 176 patients were studied and followed up to 6 weeks. Seven patients turned out to be chronic hypertension. One hundred sixty nine patients were studied finally.

The patients age ranged from 18 years to 39 years. Majority $131(87.51 \%)$, of them were $20-30$ years. Sixty five $(39 \%)$ patients were of gestational hypertension group. Preeclampsia patients were $100(59 \%)$ and eclampsia patients were $4(2 \%)$.

Ninety patients $(53.25 \%)$ were primigravidas were as $79(46.75 \%)$ multigravidas. It showed similarity in both groups. Average gestational age was between 30 and 36 weeks in $88(52.07 \%)$ patients. Standard investigations were performed in all cases as per the patients clinical scenarieo.

Only one patient had body mass index less than 18 where as the majority, $108(63.91 \%)$ of them had body mass index values between 26 and 30.55. Body mass index of more than 35 was found in 9 patients. Past history of preeclampsia was found in 11 patients. One hundred fourty three patients required antihypertensive drugs. Antepartum steroids given for lung maturity of fetus in 42 patients. Around 40 patients required magnesium sulphate.

Induction of Labour was done in 136 patients. There were $99(59 \%)$ term deliveries. Seventy $(41 \%)$ of them were preterm deliveries. One hundred fifty six singleton pregnancies. Sixteen were twin gestation. Around 3 were triplets. There was one case of single fetal demise. One hundred and thirty eight $(70 \%)$ were low birth weight babies. Forty-six $(25.14 \%)$ newborns were transferred to the neonatal intensive care unit. Intrauterine foetal death was occurred in $10(5 \%)$ of cases. Ten $(5 \%)$ were still births. Intrauterine growth retardation seen in $15.38 \%$ of patients.

Non significant proteinuria was found in $102(59 \%)$ of cases and 67(40\%) had significant proteinuria $(\geq 300$ $\mathrm{mg}$ /day). During fallow up 7 patients found to be chronic hypertension cases.

There is a good correlation found between the spot urine protein to creatinine value $(\mathrm{mg} / \mathrm{mg}$ ) and the 24 -hour urine protein $(\mathrm{mg} / \mathrm{mg})$

The area under the ROC curve is 0.999 (95\% confidence interval). The protein to creatinine value for significant proteinuria was 0.285 . The sensitivity was $100 \%$. Specificity was 99 . The positive predictive value $100 \%$. Negative predictive values was $99 \%$.

\section{Discussion}

In the present study there is a good correlation found between the spot urine protein to creatinine value $(\mathrm{mg} / \mathrm{mg})$ and the 24-hour urine protein $(\mathrm{mg} / \mathrm{mg})$ with $\mathrm{P}$ value of $<0.0001$ (two tailed), and an excellent correlation coefficient $(\mathrm{r}=0.9778)$, with a $95 \%$ confidence interval of 0.9700 to 0.9836 , for the spot urine protein to creatinine value (mg/mg) and 24-hour urine protein (mg/day) calculated by Pearson's method (Table 1).

Table 1: Correlation coefficient between the spot urine protein to creatinine value $(\mathrm{mg} / \mathrm{mg})$ and the 24 -hour urine protein (mg/day) calculated by Pearson's method.

\begin{tabular}{|c|c|c|c|c|}
\hline Number of patients & $\begin{array}{c}\text { P value } \\
\text { (two tailed) }\end{array}$ & $95 \%$ confidence interval & $\begin{array}{c}\text { Correlation } \\
\text { coefficient }(\mathrm{r})\end{array}$ & $\begin{array}{c}\text { Coefficient of } \\
\text { determination }(\mathrm{r} 2)\end{array}$ \\
\hline 169 & $<0.0009$ & $0.9700-0.9836$ & 0.9778 & 0.9561 \\
\hline
\end{tabular}

The coefficient of determination found to be 0.9561 . Table 2 shows the results of previous studies in comparision with present study.

Table 2: Comparision of present study with previous studies

\begin{tabular}{|l|c|c|}
\hline \multicolumn{1}{|c|}{ Studies } & $\begin{array}{c}\text { Correlation } \\
\text { coefficient }\end{array}$ & P-values \\
\hline Ginsberg et al.6 & 0.93 & $<0.001$ \\
\hline Neithardt et al.7 & 0.93 & $<0.001$ \\
\hline Robert et al.8 & 0.94 & $<0.001$ \\
\hline Boler et al.9 & 0.99 & $<0.001$ \\
\hline Saudan et al.3 & 0.93 & $<0.001$ \\
\hline Young et al.10 & 0.80 & $<0.001$ \\
\hline Jaschevatzky et al. ${ }^{11}$ & 0.92 & $<0.001$ \\
\hline Present study & 0.98 & $<0.001$ \\
\hline
\end{tabular}

ROC curves for the spot urine protein to creatinine ratio show an area under the ROC curve of $0.999(95 \%$ confidence interval)

The significant value of 0.285 results in a sensitivity of $100 \%$, specificity of $99.02 \%$, positive predictive value of $99 \%$, and negative predictive value of $100 \%$, with a $67 \%$ likelihood ratio. 


\section{Conclusion}

Proteinuria in pregnancy has considerable clinical importance outcome of pregnancy. For the course of pregnancy and the perinatal and maternal outcomes. So early detection with preventive measures will have greater impact on maternal and neonatal health.

Commonly used Dipstick analysis lacks reliability. False positives results are more with this test. One complete day urine collection method is cumbersome. It has so many for protein errors. Most obvious error is variable and complete collection is difficult. It may be inconvenient for many patients. There are incidences of delay in availability of results. Patient may deliver before the arrival of results. Difficulty in arranging storage and staff inadequacy are added problems. Admission of patient for the test itself is burden to hospital.

Urine protein to creatinine value may be a good solution for the above mentioned problems. Since it has shown good results and showed comparable reports with the 24-hour urine protein.3-5 So urine protein to creatinine value can be used as an alternative to 24 hour urine protein for clinical purposes.

Random sample assessment is more convenient. It will be more acceptable to the patients. In hypertensive disorders of pregnancy investigations needs to be repeated often too. Practically waiting for one day for report is also not a good option. So random sample assay appears to be good option.

The value of urine protein to creatinine is $0.285 \mathrm{mg}$ protein $/ \mathrm{mg}$ creatinine is considered for significant proteinuria. If value lower than 0.285 need not be associated with significant proteinuria. Hence further testing can be avoided. It can provide valuable information if interpreted properly for clinical purposes and is a satisfactory substitute for 24-hour protein estimation.

\section{Limitations}

The present study has limitation of hospitalised patients who were non-ambulatory patients. Proteinuria will be affected by postural changes. So it may be a confounding factor in the quantitation of proteinuria.

\section{Acknowledgements}

I would like to thank professor Dilip Kumar Mayurya for his encouragement throught this difficult project

\section{Conflict of Interest: None.}

\section{References}

1. Report of the national high blood pressure education program working group on high blood pressure in pregnancy. Am J Obstet Gynecol 2000;183(1):S1-22.

2. Saudan P, Brown MA, Buddle ML, Jones M. Does gestational hypertension become pre-eclampsia? Br J Obstet Gynaecol 1998;105(11):1177-84.

3. Saudan PJ, Brown MA, Farrell T, Shaw L. Improved methods of assessing proteinuria in hypertensive pregnancy. $\mathrm{Br} \mathrm{J} \mathrm{Obstet}$ Gynaecol 1997;104(10):1159-64.

4. Waugh JJ, Bell SC, Kilby MD, Blackwell CN, Seed P, Shennan AH et al. Optimal bedside urinalysis for the detection of proteinuria in hypertensive pregnancy: a study of diagnostic accuracy. BJOG 2005;112(4):412-7.

5. Kyle PM, Fielder JN, Pullar B, Horwood LJ, Moore MP. Comparison of methods to identify significant proteinuria in pregnancy in the outpatient setting. BJOG 2008;115(4):523-7.

6. Ginsberg JM, Chang BS, Matarese RA, Garella S. Use of single voided urine samples to estimate quantitative proteinuria. N Engl J Med 1983;309(25):1543-6.

7. Neithardt AB, Dooley SL, Borensztajn J. Prediction of 24-hour protein excretion in pregnancy with a single voided urine protein-to-creatinine ratio. Am J Obstet Gynecol 2002;186(5):883-6

8. Robert M, Sepandj F, Liston RM, Dooley KC. Random protein-creatinine ratio for the quantitation of proteinuria in pregnancy. Obstet Gynecol 1997;90(6):893-5.

9. Boler L, Zbella EA, Gleicher N. Quantitation of proteinuria in pregnancy by the use of single voided urine samples. Obstet Gynecol 1987;70(1):99-100.

10. Young RA, Buchanan RJ, Kinch RA. Use of the protein/creatinine ratio of a single voided urine specimen in the evaluation of suspected pregnancy-induced hypertension. $J$ Fam Pract 1996;42(4):385-9.

11. Jaschevatzky OE, Rosenberg RP, Shalit A, Zonder HB, Grunstein $S$. Protein/creatinine ratio in random urine specimens for quantitation of proteinuria in preeclampsia. Obstet Gynecol 1990;75(4):604-6.

12. Leanos-Miranda A, Marquez-Acosta J, Romero-Arauz F, Cardenas-Mondragon GM, Rivera-Leanos R, Isordia-Salas I, et al. Protein:creatinine ratio in random urine samples is a reliable marker of increased 24-hour protein excretion in hospitalized women with hypertensive disorders of pregnancy. Clin Chem 2007;53(9):1623-8.

13. Ramos JG, Martins-Costa SH, Mathias MM, Guerin YL, Barros EG. Urinary protein/creatinine ratio in hypertensive pregnant women. Hypertens Pregnancy 1999;18(3):209-18

14. James PR, Nelson-Piercy C. Management of hypertension before, during, and after pregnancy. Heart 2004;90(12):1499504.

15. Rodriguez-Thompson D, Lieberman ES. Use of a random urinary protein-to-creatinine ratio for the diagnosis of significant proteinuria during pregnancy. Am J Obstet Gynecol 2001;185(4):808-11.

16. Yamasmit W, Chaithongwongwatthana S, Charoenvidhya D, Uerpairojkit B, Tolosa J. Random urinary protein-to-creatinine ratio for prediction of significant proteinuria in women with preeclampsia. J Matern Fetal Neonatal Med 2004;16(5):275-9.

How to cite this article: Nipanal HV, Sushmitha $\mathrm{S}$, Significance of Protein: Creatinine value in PIH. Indian J Obstet Gynecol Res 2019;6(2):141-143. 